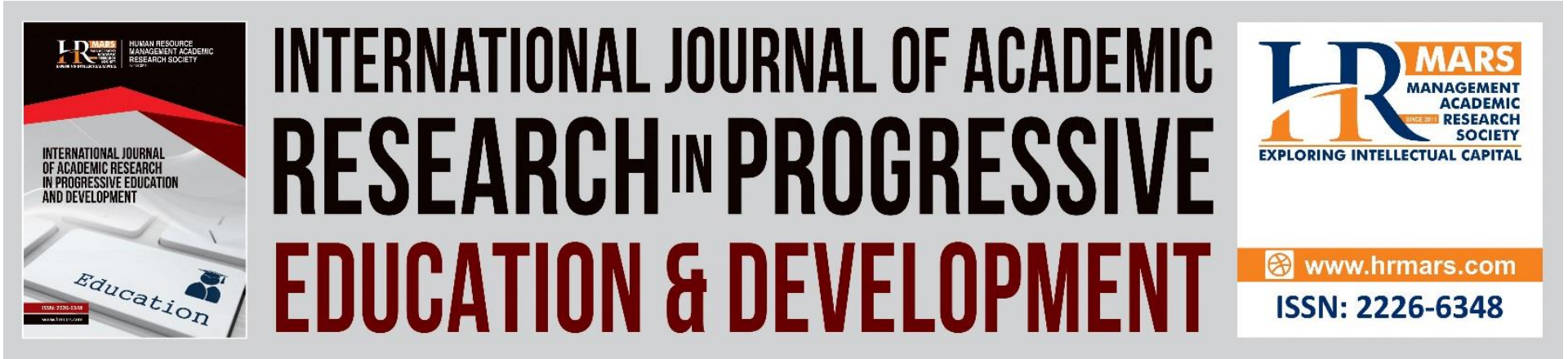

\title{
Education Based on Qalbur. A Study on the Quality of Teachers According to the Islamic Worldview
}

\author{
Amir Mohd Nason, Mohd Shukri Hanapi \& Shahirah Said \\ To Link this Article: http://dx.doi.org/10.6007/IJARPED/v10-i3/11543 \\ DOI:10.6007/IJARPED/v10-i3/11543
}

Received: 16 July 2021, Revised: 21 August 2021, Accepted: 08 September 2021

Published Online: 25 September 2021

In-Text Citation: (Nason et al., 2021)

To Cite this Article: Nason, A. M., Hanapi, M. S., \& Said, S. (2021). Education Based on Qalbu: A Study on the Quality of Teachers According to the Islamic Worldview. International Journal of Academic Research in Progressive Education and Development, 10(3), 1146-1156.

Copyright: (C) 2021 The Author(s)

Published by Human Resource Management Academic Research Society (www.hrmars.com)

This article is published under the Creative Commons Attribution (CC BY 4.0) license. Anyone may reproduce, distribute, translate and create derivative works of this article (for both commercial and non-commercial purposes), subject to full attribution to the original publication and authors. The full terms of this license may be seen

at: http://creativecommons.org/licences/by/4.0/legalcode

\section{Vol. 10(3) 2021, Pg. 1146 - 1156}

Full Terms \& Conditions of access and use can be found at http://hrmars.com/index.php/pages/detail/publication-ethics 


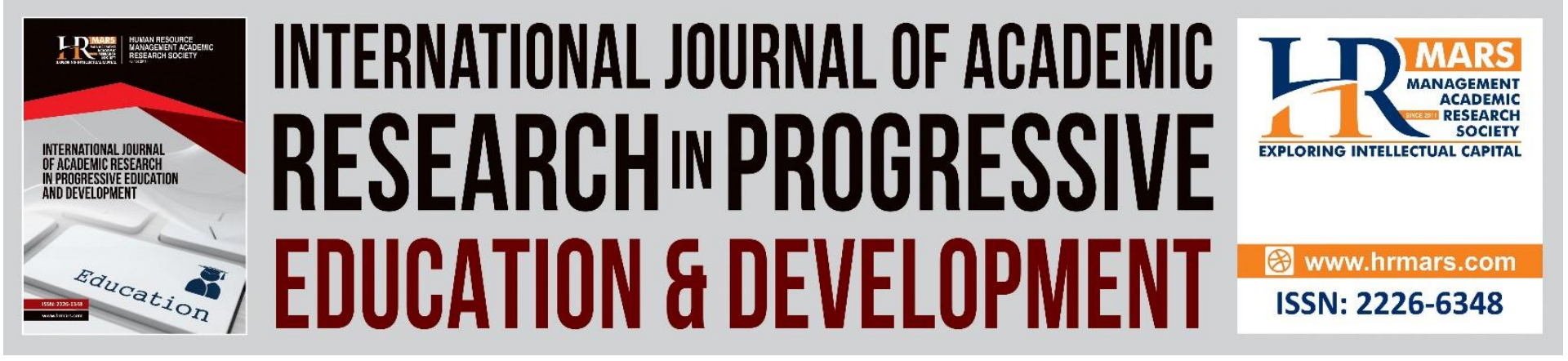

\title{
Education Based on Qalbur. A Study on the Quality of Teachers According to the Islamic Worldview
}

\author{
Amir Mohd Nason ${ }^{1}$, Mohd Shukri Hanapi ${ }^{2}$ \& Shahirah Said ${ }^{3}$ \\ ${ }^{1}$ Department of Islamic and Moral Education, Sultan Abdul Halim Institute of Teacher \\ Education, 08000 Sungai Petani, Kedah, Malaysia, ${ }^{2}$ Centre for Islamic Development \\ Management Sudies (ISDEV), Universiti Sains Malaysia, 11800 USM, Penang, Malaysia, \\ ${ }^{3}$ Academy of Contemporary Islamic Studies (ACIS), Universiti Teknologi MARA (UiTM), \\ Cawangan Pulau Pinang Kampus Permatang Pauh, 13500 Permatang Pauh, Penang, \\ Malaysia.
}

\begin{abstract}
This working paper intended to discuss the meaning of quality teachers according to Islam and the effect of quality teachers on education based on qalbu. The issue pertaining to quality teachers is frequently discussed by various parties, especially when there is a problem among students. One view states that teachers today are void of the quality and soul of an educator, which minimises the effects of the education agenda and aim at all levels. This situation leads two questions. First, what is the meaning of the quality of teachers according to the Islamic worldview? Second, how can the quality of teachers affect education based on qalbu? This study intended to answer these questions by adopting a qualitative method that used content analysis. The results show that quality of teachers is a priority in Islam according to Islamic worldview, which is based on revealed knowledge sourced from the al-Qur'an and al-Sunnah as well as views from scholars on Islamic education. It is intended to guarantee the success of education and have a direct affect on the success of the education agenda based on qalbu.
\end{abstract}

Keywords: Education, Qalbu, Quality of Teachers, Islamic Worldview

\section{Introduction}

Contemporary society is interested in developing their own education system in order to achieve the highest quality in educational products. The issue of quality education has attracted many parties involved in education at the regional and global level. In addition, many believe that one way to face the challenges of the $21^{\text {st }}$ century is to enhance the quality and productivity of education.

Muslims should be the main motivators in exploring a level of perfection for achieving high standards and quality in all aspects of work, especially in the field of education. Islam emphasises this aspect on all its subjects. Hence, this is why Muslims are required to be committed in their worship, morality and any sorts of work by ensuring that it is done properly. Islam is the best platform for comprehensively enhancing quality in all aspects of 
life and work, either in the form of words, actions or practices. This matter is explained by Allah SWT in HIS exhortation:

"And who is better in religion than one who submits himself to Allah while being a doer of good and follows the religion of Abraham, inclining toward truth? And Allah took Abraham as an intimate friend." (al-Nisa, 4: 125)

History has shown that well disseminated or delivered Islamic education has created and built a Muslim civilization that has been enjoyed by humankind for a very long time. This civilization has served humankind by developing exquisite knowledge. This continued until the civilization was destroyed by political anarchy, economic recession, infiltration of western culture through war and colonization of Islamic countries, which then led to the downfall of the education system and its quality. These circumstances have also led to the decline of the Muslims in various fields (Abu-daf, 2007).

The Ministry of Education Malaysia and Ministry of Higher Education have an agenda, which is to develop a world-class education system that serves the highest quality of education. Hence, based on this important agenda, teachers are directly involved in implementing efforts and teaching approaches to improve the quality of teaching and ensure students receive the maximum outcome from the learning process in schools. This is because properly planned quality education can only be produced when motivators of educational development, namely teachers, are effective and are at the highest level of professionalism. Inevitability, education itself cannot be developed or expanded without the participation and involvement of good quality and excellent teachers. Teachers act as a catalyst that enhances the effectiveness of education, which then produces humans who are excellent from a holistic aspect.

\section{Education Based on Qalbu and the Islamic Worldview}

There are two main tools used as mediums for delivering information in the education process, which are the mind and the heart (Ismail, 2016; Rosdi, 2015). Both these tools form the education strategies, methods and approaches in the context of mind-to-mind, mind-toheart, heart-to-mind and heart-to-heart (based on qalbu). Among these four methods, education based on the heart is discussed because the mind-to-mind, mind-to-heart, heartto-mind methods only focus on knowledge without practising it. This differs from the method and approach based on qalbu, which not only focuses on knowledge but also on its practices (Salleh, 2003).

Education based on qalbu emphasises on the continuous and permanent cleansing of the heart (tazkiyah al-nafs) (Rosdi, 2015). Salleh (2003) outlined four remedies for treating the heart. First, eliminate the element of mazmumah, such as the ego, 'ujub (self-pride or selfdeceit) and takabbur (overzealous pride); second, to consume halal and clean food; third, to istiqamah (be steadfast) when seeking knowledge; fourth, always reminiscent about death; and fifth, always read, understand and practice the al-Qur'an. 
According to Zaki (2016: 94), a teacher who uses the heart as part of the approach in the teaching and learning process to deliver knowledge to students, will have the knowledge delivered directly to the student's heart.

The mind-to-mind approach in education will only be exhibited when teachers and students are able to separate knowledge from behaviour. They know many things but rarely practice it, what more advocate it. It will be strange to see students practicing knowledge while teachers themselves only comprehend and convey the knowledge, but hardly reflect this knowledge in their behaviour (Salleh, 2003: 25). This characteristic is loathed by Allah SWT, as $\mathrm{HE}$ exhorted in the following verse.

"It is most loathsome in the sight of Allah that you should profess what you do not practise" (al-Saff, 61: 3).

Therefore, the consequence of combining the mind with the heart and knowledge with its practice is the creation of a person who is pious, devotes oneself to Allah SWT and relies on the belief in Allah SWT on this earth. Knowledge educates the heart, and then the heart educates the mind. The mind functions as a guide, while the practice of knowledge is akin to a follower. Followers without a guide can get lost, whereas a guide with no followers is a waste. With the combination of the mind with the heart as well as knowledge with its practice, the knowledge becomes the "food" or the heart and enlivens the heart (Salleh, 2003). Conversely, knowledge is not only solely understood by the mind but should also be understood by the heart (Salleh, 2003).

The formation and building of the qalbu-based education approach rely on the Islamic worldview and epistemology. These two elements are the fundamentals to all fields of knowledge (Salleh, 2008). Tasawwur (worldview) refers to the picture that depicts life, which forms the basis of confidence and the various practices of faith by humans (Salleh, 2003). Islamic worldview and epistemology rely on divine deliverance (wahyu). Divine deliverance also instructs a Muslim to educate and be educated. Education based on divine deliverance produces an individual of good quality and balanced character (Lubis, 2015). This is further consolidated by referring to Islam's other main sources besides the al-Quran, which is the alSunnah, ljmak and Qiyas (Ismail, 2016). According to Qutb (t.t: 39), Islamic worldview originated from Allah SWT with all its characteristics and components. Its characteristics and components are completely accepted by humans, who have not enhanced or deprecated anything. Nevertheless, humankind's role is to familiarise oneself and practice it in the course of one's life.

\section{The Quality of Education According to Islam}

Islam places great importance on quality and calls on its subjects to be always assiduous and benevolent, which is defined by al-Attas (2010: 12) as the best achievement when carrying out a task or job. This is emphasised by the Prophet SAW in the hadith below:

From Syaddad bin 'Aws, "Two thing I always remember about the Prophet SAW is HIS exhortation, "Verily Allah has made it obligatory to always have a good attitude about anything because when one of you wants to kill, then kill the best way and when one 
of you wants to slaughter, then slaughter it properly using a sharp knife that causes the least discomfort to what is being slaughtered." (Muslim, 1998: 1955)

In another hadith, the Prophet SAW exhorted:

"Verily Allah SWT like a person among you all who carries out a pious practice with itqan" (al-Tabarani, 897; al-Baihaqi, 5312)

Education is a practice that places importance in quality when it is implemented. Quality in education is a building process that is designed with the aim of improving its product (Abudaf, 2007: 9). According to 'Alimat (2004), quality of education consists of three elements. First is the quality of the design, which determines and establishes the form, specification and features of education. Second is the quality of performance, which refers to an action based on an established specification, and third is the quality of output, which refers to the educational product or service based on the established features and specifications.

The quality of education is inseparable from the quality of teachers. This is because teachers, who are directly involved in $21^{\text {st }}$ century education, should possess a strong mind and good personality in order to face the challenges of education. Teachers not only produce human capital that is knowledgeable and highly skilled in industry, technology, services, management as well as commerce and economy but should also produce individuals who possess good values, ethical and moral systems, a noble personality, a high sense of responsibility, strict obedience to Allah SWT and the capability to help build and develop a nation.

This was mentioned by al-Khatib in Abu-daf (2007: 9), who said that from an Islamic perspective, the quality of education is translated as all the needs and hopes accruing from the education process that culminates in a specific characteristic when designing and planning the education service and the method for implementing it in order to fulfil the needs and hopes of society, and more importantly, securing the blessings of Allah SWT.

\section{Quality of Teachers According to the Islamic Worldview}

Al-Ghazali (2011) had produced a model for good quality and excellent teachers by focusing on several aspects that should be present in a teacher's soul and practices. Al-Ghazali (2011) had highlighted two aspects, namely love and sympathy towards students' needs. This happens when the teacher treats the student as his/her own child and caters to every need of the child. Besides that, good quality and excellent teachers should be assiduous when practicing the Prophet's SAW hadith in all aspects of life. Moreover, good quality and excellent teachers are teachers who do not ask for remunerations and rewards when carrying out their duties as educators. In addition, al-Ghazali (2011) also emphasised that teachers should always advice their students against getting involved in prohibited acts and vice in a polite and constructive manner.

According to Jasmi and Nawawi (2012: 234), the al-Ghazali (2011) quality of teachers model shows that piousness and the relationship with Allah SWT are the fundamentals of an educator who intends to change and form students behaviour. An established and strong faith helps produce an ideal, pure and noble personality, which an individual should possess. Each 
teacher should have a high command of communication skills, religious knowledge and subject content that will be delivered to students.

Al-Nadwi (1965: 17) also explained that good quality teachers can explain the aim and intention of education to their students. Each student needs to understand that the main aim of learning, which is to achieve peace on this earth and the afterlife, save them and their families from Allah SWT's fire of hell, the displeasures of Allah SWT, living in ignorance (jahiliyah) and help humanity escape from the darkness and witness the light and fairness of Islam. Hence, al-Nadwi (1965: 24) stressed that for the education agenda to be successful through teaching and learning, the selection of teachers is an important stage that needs proper attention. A teacher is not selected solely because of academic achievements, but other aspects such as moral values and personality, principles and its aim as well as faith and beliefs. These important aspects should receive special attention when selecting teachers in order to ensure that teachers actually possess qualities according to Islam.

Jasmi and Nawawi (2012) had built the Excellent Teacher in Islamic Education Model. The Excellent Teacher in Islamic Education Model is a useful guide, especially for Islamic Education Teachers, in efforts to enhance the quality of teachers and their teaching methods to produce excellent and motivated students. The Excellent Teacher in Islamic Education Model focuses on several important aspects that should exist and be practiced by teachers, which are the teaching and learning, personality and skills aspects. Effective and good quality teachers should emphasise on assimilating the vision and mission, besides preparing the teaching and learning, induction sets, approach and implementation, class management, teaching aids (BBM) and evaluation as well as closure, which is an important element in the effectiveness of a teaching and learning.

Besides that, the personality aspect is a causative factor in enhancing the quality of a teacher. Personality can be highlighted and practiced when worshipping Allah SWT, on oneself and on students. The behaviour and practices of teachers could set an example for students to follow. Hence, every teacher should possess a noble personality, especially Islamic education teachers. Besides that, skills and efficiency, such as in management, communication, Information and communication technology (ICT), writing, linguistics, treatment and art are also important elements in determining the quality and excellence of a teacher. Tamuri (2016: 15) also asserted the need for a teacher to possess exemplary features of a personality, a good character and portray a strong leadership in order to ensure the effectiveness of the knowledge delivery and education processes are achieved.

Abu-daf (2007: 11-19) had outlined several elements based on the Islamic worldview that form the personality of a good quality teacher. Among the elements are practising piousness, showing kindness when teaching, completing tasks properly and calling on Muslims to seek beneficial knowledge.

\section{Pious Practices (al-'Amal al-Salih)}

A teacher's practices in the education field should be pious in nature. The al-Qur'an and hadith have extensively discussed the need to practice in a pious manner. In one verse Allah SWT exhorted: 
"And who is better in speech than one who invites to Allah and does righteousness and says, indeed, I am of the Muslims." (Fussilat, 41: 33)

The Prophet SAW had outlined a dimension for pious practices, which is the capability to provide benefits to others. This was explained in a hadith where the Prophet SAW exhorted:

"A Muslim will not plant a crop which is them consumed by humans, animals or even birds, unless that crop is a form of sedoqah for him until the Day of Resurrection." (Riwayat Ahmad)

According to al-Kaylani (1996: 16-19), the piousness concept in Islam is comprehensive in character. It is not confined solely to good and beneficial behaviour but also all prohibitions concerning acts of vice. The practice of piousness also touches on morality and success. When one who has moral values is unsuccessful, then one cannot reap the benefits while just rejecting what is immoral. Similarly, when one is successful but is immoral, one will only invite the negative elements in life. Morality and success should combine in order to provide benefits, not be deleterious in nature (al-Kaylani, 1988: 49).

The al-Qur'an has explained humanity's journey of life in this world and the afterlife by measuring the gains and losses based on three elements, namely faithfulness, practicing piousness and giving advice in a truthful and patient manner (al-'Asr, 103: 1-3). The Prophet SAW also indicated that the best kind of life for a human will be for him to do good for the benefit of others. Practicing piousness is a prerequisite for a subject who wishes to meet Allah SWT (al-Kahfi, 18: 110).

Besides that, the al-Qur'an also suggests that one should fervently endeavour to carry out pious practices (al-Baqarah, 2: 148) and Allah SWT will reward them with a place in heaven and all the pleasures therein (al-Waqi'ah, 56: 10-12).

\section{Benevolence (Ihsan) in Educating}

Allah SWT had strongly emphasised on benevolence when carrying out any pious practice. This is clear when Allah SWT exhorted as follows:

"Indeed, Allah orders justice and good conduct and giving to relatives and forbids immorality, bad conduct and oppression. He admonishes you that perhaps you will be reminded." (al-Nahl, 16: 90)

In another verse in the al-Qur'an, Allah SAW had combined faith, piousness and benevolence as elements that Allah SWT liked to see in HIS subjects (al-Ma'idah, 5: 93). Allah SWT also emphasised that a comprehensive manhaj-Islami (Islamic method) should infiltrate every scope of human life. Allah SWT further stressed that every practice in life is a test that will determine the good and bad in the afterlife (al-Kahfi, 18: 7; al-Mulk, 67: 2).

The Prophet SAW had also mentioned about being benevolent when carrying out practices. This was stated in several hadith, one of which is mentioned below: 
"When the time for a prescribed prayer comes, if any Muslim performs ablution well and offers his prayer with humility and bowing, it will be an expiation for his past sins, so long as he has not committed a major sin; and this applies for all times." (Muslim, 1998: 228)

This shows that being benevolent is part of the teachings in Islam. Benevolence refers to a high standard of morality, which is needed to build a relationship with Allah SWT when an individual worships Allah SWT. Teaching and learning are part of worship; hence, teachers as the main pillar in the teaching and learning process should be benevolent when carrying out their duties with the hope of receiving blessings from Allah SWT (Abu-daf, 2007: 13).

\section{Finishing a Task Properly}

Islam is a religion that is perfect and void of any deficiencies (al-Ma'idah, 5: 3). Finishing a task is one of the criteria for honouring an agreement and this was elaborated by Allah SWT in the story concerning the Prophet of Allah Syu'ib a.s and the Prophet of Allah Musa a.s, as mentioned in the verse below:

"Her father said to Moses: "I want to marry one of these two daughters of mine to you if you serve me for eight years. But if you complete ten years, that will be of your own accord (but not an obligation). I do not intend to treat you harshly. If Allah wills, you will find me an upright man." (al-Qasas, 28: 27)

Finishing a task is a building process that compliments both the committed effort and continuity. Continuity refers to the doubling of efforts by checking, evaluating and assessing tasks although many might feel that the task has been completed. In order to ensure that the education product is proper, comprehensive and fulfils the aims and target of education, teachers should possess Islamic values and system. This is elaborated as follows:

\section{Sincerity in Worship in the Name of Allah}

Sincerity is defined as distancing all practices and actions from an evil heart or soul, such as the desire to be praised, demanding for rewards, self pride or self-deceit and all things that destroy a sacred heart (al-Jawziyyah, 2011: 1564). Moreover, each employee must have sincere intentions when working and sincerity is built when one fears Allah SWT. This is because the fear of Allah SWT will invite Allah's muraqabah until a person is assiduous and careful in his work in order to be consistent with the Islamic worldview. Allah SWT has clearly instructed HIS subjects to worship with sincerity (al-Bayyinah, 98: 5).

Among the elements associated with worshipping with sincerity are carrying out an act of worship or task in a proper manner as well as acting assiduously and cautiously. Thus, acting in this manner when doing any work reflects the characteristics of sincerity in an employee, including teachers.

\section{Trust in Carrying out Tasks}

Trust is a characteristic that a mukmin should possess (al-Mukminun, 23: 8). The Prophet SAW also cautioned that humans should use and exchange knowledge wisely because the biggest betrayal will occur to knowledge (al-Tabarani, 1983: 270). Proof of a teacher's trust in carrying 
out tasks is reflected in the commitment to teach and educate, be punctual and not find excuses for being absent from class.

\section{Showing Responsibility Towards Tasks}

Undeniably, each individual who has a sense of responsibility towards a task will ensure that each task is carefully carried out with the highest level of quality. This is due to the awareness that one's life that will be scrutinised in front of Allah SWT, whereby one's practices will be made known or will remain a personal secret. Allah SWT exhorted:

"To Allah belongs whatever is in the heavens and whatever is in the earth. Whether you show what is within yourselves or conceal it, Allah will bring you to account for it. Then He will forgive whom He wills and punish whom He wills, and Allah is over all things competent." (al-Baqarah, 2: 284).

Good quality teachers will ensure that each task is carried out to the best of their ability with the fullest sense of responsibility.

\section{Calling Muslims to Possess Beneficial Knowledge}

Good quality teachers always ensure that students are encouraged to possess beneficial knowledge, which is a type of knowledge that is put to practice. According to al-Najjar (1981: 122), beneficial knowledge is knowledge that connects humans to Allah SWT, which then enables humans to develop an Islamic-based caliphate (khilafah) on this earth. The measurement of beneficial knowledge is unlike pragmatic philosophy, which is seen from the materialistic and earthly perspectives. However, beneficial knowledge fulfils human needs and at the same time develops religion ('Ali, 1992). Utilization of knowledge is among the elements of quality possessed by teachers and those who seek knowledge.

\section{Conclusion}

Based on the discussions above, it can be concluded that the quality of teachers according to the Islamic worldview is an important element for the success of qalbu-based education. Qalbu-based education is education that emphasises on the qualities of a good heart (compassionate, kind, patient, committed, trustworthy etc.) as a tool for delivering and receiving knowledge. Qalbu-based education emphasises on a sacred heart through the tazkiyah al-nafs process, which has a direct effect on the process of creating quality teachers. Among the criteria that a good quality teacher should possess according to the Islamic worldview are pious practices, kindness when teaching, carrying out tasks properly including being sincere in worship in the name of Allah, being trustworthy and responsible when carrying out duties and calling on fellow Muslims to possess beneficial knowledge. Good quality teachers are a priority in Islam according to revealed knowledge found in the alQur'an, al-Sunnah and the views of Islamic education scholars. This is intended to ensure the success of education and the direct effect it has on the successful implementation of qalbubased education, which guarantees excellence in this world and in the afterlife. 
DEVELOPMENT

Vol. 10, No. 3, 2021, E-ISSN: 2226-6348 @ 2021 HRMARS

\section{Corresponding Author}

Amir Mohd Nason

Department of Islamic and Moral Education, Sultan Abdul Halim Institute of Teacher Education, 08000 Sungai Petani, Kedah, Malaysia.

Email: amir@ipsah.edu.my

\section{References}

Abu-Daf, M. K. (2007). Jawdah al-Ta'lim fi al-Tasawur al-Islamiy: Mafahim wa Tatbiqat [Paper presentation]. Muktamar al-Jawdah fi al-Ta'lim al-'Am al-Falistini ka Madkhal li alTamayyuz.

Al-Attas, S. M. N. (2010). Dewesternisasi Ilmu, Jurnal Terjemahan Alam \& Tamadun Melayu, Universiti Kebangsaan Malaysia (UKM). 1 (3-20).

Al-Ghazali, A. H. M. (2011). Ihya' Ulum al-Din. Jeddah: Dar al-Minhaj.

Ali, S. I. (1992). Ahdaf al-Tarbiyyah al-Islamiyyah. Majallah al-Muslim al-Mu'asir, Mu'assasah Muslim al-Mu'asir \& Ma'ahad al-'Alamiy li al-Fikr al-Islamiy. 63.

'Alimat, S. N. (2004). Idarah al-Jawdah fi al-Muassasat al-Tarbawiyyah. Jordan: Dar al-Syuruq. Al-Jawziyyah, I. Q. M. (2011). Madarij al-Salinikin. Riyadh: Dar al-Samimi.

Al-Kaylani. M. I. (1988). Ahdaf al-Tarbiyyah al-Islamiyyah. Madinah al-Munawwarah: Makabah Dar al-Turath.

Al-Nadwi, A. H. A. (1969). Nahw al-Tarbiyyah al-Islamiyyah al-Hurrah fi al-Hukumat wa alBilad al-Islamiyyah. Beirut, Lubnan: Dar al-Irsyad.

A-Najjar, R. Z. (1977, October 11). "Azmah al-Ta'lim al-Mu'asir wa Hululuha al-Islamiyyah", Majallah al-Muslim al-Mu'asir, Mu'assasah Muslim al-Mu'asir \& Ma'ahad al-'Alamiy li al-Fikr al-Islamiy. 11.

Ismail, N. H. (2016). Teori Pembelajaran Lazim: Analisis Dari Perspektif Islam [Paper Presentation]. Seminar Islam dan Kelestarian Ummah Peringkat Serantau (SIDKUN 2016), organised by School of Languages, Civilization \& Philosophy (SCLP), Pusat Islam, Universiti Utara Malaysia (UUM).

Jasmi, K. A., \& Nawawi, N. F. (2012). "Model Guru Berkualiti dari Perspektif Tokoh Pendidikan Islam dan Barat", Prosiding Seminar Antarabangsa Perguruan dan Pendidikan Islam [SEAPPI2012]. Seri Begawan, Brunei: Kolej Universiti Perguruan Utama Seri Begawan (KUPUSB), 233-238.

Lubis, M. A. (2015). "Effective Implementation of the Integrated Islamic Education", Global Journal Al-Thaqafah. 5 (1), 59-68.

Muslim, H. M. (1998). Sahih Muslim. Riyadh: Bayt al-Afkar al-Dawliyyah li al-Nasyr.

Qutb, S. (n.d.). Khasa'is al-Tasawwur al-Islamiy wa Muqawwimatih. Jordan: Dar al-Syuruq.

Rosdi, M. S. M. (2015). Strategi Pendidikan Hati ke Hati: Pengalaman di Pusat Kajian Pengurusan Pembangunan Islam (ISDEV), Universiti Sains Malaysia. Jurnal Kemanusiaan, Fakulti Pengurusan, Universiti Teknologi Malaysia. 24(3), 40-63.

Said, N. A., \& Khairuldin. (2017). Freedom of Speech in Islam and its Connection with Street Demonstrations. International Journal of Academic Research in Business and Social Sciences, 7(4), 122-129.

Khairuldin, Embong, A. H., Anas, W. N. I. W. N., Ismail, D., Ibrahim, I., \& Fauzi, N. (2017). Freedom of Speech: A Comparative Study between Islam and Malaysian Laws. International Journal of Academic Research in Business and Social Sciences, 7(2), 2222-6990. 
Ibrahim, I., \& Khairuldin. (2017). Fatwa as a Medium Da'wah: Studies on the Role of Mufti as a Preacher. International Journal of Academic Research in Business and Social Sciences, 7(4), 10-18.

Salleh, M. S. (2003). Pengurusan Pembangunan Berteraskan Islam: Konsep dan Perkaedahan (Siri Syarahan Umum Perlantikan Profesor). Pulau Pinang: Penerbit Universiti Sains Malaysia.

Salleh, M. S. (2008). Pengajaran-Pembelajaran Hati ke Hati dan Implikasinya ke Atas Pembinaan Masyarakat (Teaching-Learning from Heart to Heart and Its Implication on Societal Building), invited speaker at Konvokesyen Universitas Pembinaan Masyarakat Indonesia (UPMI) ke-18, organized by Universitas Pembinaan Masyarakat Indonesia (UPMI), Medan, Indonesia, 8 November.

Tamuri, A. H., \& Ajuhary, M. K. A. (2010). Amalan Pengajaran Guru Pendidikan Islam Berteraskan Konsep Mu'allim. Journal of Islamic and Arabic Education. 2 (1), 43 - 56.

Tamuri, A. H. (2016). "Keberkesanan Guru Dalam Pengajaran dan Pembelajaran Mata Pelajaran Pendidikan Islam", in Mohd Farid Mohd Shahran \& Nor Hartini Saari (eds.), Guru Cemerlang Pendidikan Islam: Persedian dan Cabaran. Kuala Lumpur: Institut Kefahaman Islam Malaysia (IKIM). 1-30.

Zaki, M. M. M. (2016). Pendidikan Hati Ke Hati Berdasarkan Amalan Qalbu (Teaching and Learning Based on Qalb Practice). Dissertation, Centre for Islamic Development Management Studies (ISDEV), Universiti Sains Malaysia, Pulau Pinang. 